\title{
Identifikasi Ciri Eksterior Ternak Babi Jantan pada Peternakan Rakyat di Kecamatan Atambua Selatan Kabupaten Belu
}

\author{
Nonia A. Maikameng ${ }^{\mathrm{a}}$, dan Veronika Yuneriati Beyleto ${ }^{\mathrm{b}}$ \\ ${ }^{a}$ Fakultas Pertanian, Universitas Timor, Kefamenanu, TTU - NTT, 85613, Indonesia. \\ ${ }^{b}$ Fakultas Pertanian, Universitas Timor, Kefamenanu, TTU - NTT, 85613, Indonesia.
}

\section{Article Info}

\section{Article history:}

Received 15 Juni 2016

Received in revised form 15 September 2016

Accepted 17 September 2016

\section{Keywords:}

Ciri Eksterio

Babi Jantan

Atambua Selatan

\begin{abstract}
Abstrak
Penelitian ini dilaksanakan di Kecamatan Atambua Selatan Kabupaten Belu dengan tujuan untuk mengetahui ciri eksterior ternak babi jantan yang ada pada wilayah ini dengan melihat pada variabel 1) warna bulu; 2) bobot badan; 3) panjang telinga; 4) panjang badan; 5) lingkar dada; dan 6) tinggi pundak. Hasil penelitian ini menunjukkan bahwa warna bulu ternak babi jantan lokal di Kecamatan Atambua Selatan pada umumnya memiliki warna bulu tebal yang berwarna hitam pekat dan tebal di seluruh tubuh ternak, sebagian pula memilik warna bercak putih-hitam, kecokelatan bercak hitam-putih, dan warna hitam yang menjadi dominan sehingga warna hitam dan bulu agak kasar menjadi karakteristik ternak babi jantan lokal, sedangkan pengukuran sifat kuantitatif pada babi lokal jantan menunjukkan bahwa rata-rata dari bobot badan jantan anak 7,66 kg, jantan muda $28,59 \mathrm{~kg}$, dan jantan dewasa 111,00 kg, pajang telinga jantan anak $8,26 \mathrm{~cm}$ jantan muda 11,42 cm dan jantan dewasa 20,44 cm, panjang badan jantan anak 36,30 cm, jantan muda 46,52 cm, dan jantan dewasa 107,67 $\mathrm{cm}$, lingkar dada jantan anak $36,30 \mathrm{~cm}$, jantan muda 46,56 cm, jantan dewasa $94,91 \mathrm{~cm}$ dan tinggi pundak jantan anak $28,84 \mathrm{~cm}$, jantan muda $36,36 \mathrm{~cm}$, jantan dewasa $62,71 \mathrm{~cm}$. Hasil pengukuran sifat kuantitatif pada ternak babi jantan peranakan VDL menunjukkan bahwa rata-rata bobot badan adalah jantan anak $11,79 \mathrm{~kg}$, jantan muda 78,31 kg dan jantan dewasa adalah 131,60 kg, panjang telinga jantan anak $10,69 \mathrm{~cm}$, jantan muda $12,79 \mathrm{~cm}$, dan jantan dewasa $21,61 \mathrm{~cm}$, panjang badan jantan anak $32,23 \mathrm{~cm}$, jantan muda $63,21 \mathrm{~cm}$, dan jantan dewasa 108,94 cm, lingkar dada jantan anak 42,83 cm, jantan muda 59,88 cm dan jantan dewasa 103,13 cm, tinggi pundak jantan anak $30,74 \mathrm{~cm}$, jantan muda $51,27 \mathrm{~cm}$ dan jantan dewasa $71,84 \mathrm{~cm}$. (02016 dipublikasikan oleh JAS.
\end{abstract}

\section{Pendahuluan}

Salah satu program pemerintah pada sub sektor peternakan adalah swasembada daging, dan dapat dilakukan dengan mengembangkan komoditas peternakan penting seperti ternak babi, baik ternak babi peranakan dan lokal. Ternak babi merupakan komoditas peternakan yang sangat erat kaitannya dengan kehidupan masyarakat di pedesaan dan perkotaan yang umumnya di pelihara oleh peternak sebagai usaha sambilan. Agar usaha peternakan babi dapat memberikan keuntungan yang optimal bagi peternak maka perlu diperhatikan beberapa hal yang menyangkut manajemen pemeliharaan yang dapat meningkatkan produktivitas ternak babi.

Keunggulan ternak babi yaitu memiliki daya pertumbuhan dan perkembangan yang relatif cepat, memiliki sifat prolifik, yaitu dalam satu kali beranak bisa mencapai 6 - 12 ekor per kelahiran dan dalam setahun dapat dua kali beranak. Untuk ternak babi jantan sebagai ternak penyedia spermatozoa dapat memudahkan dan meningkatkan penampilan produksi ternak dengan menggunakan sistem seleksi maupun inseminasi buatan agar dapat mempermudah dan mempercepat kegiatan produksi maupun perekonomian peternak sendiri, dengan seleksi ternak babi mampu menyediakan produksi daging yang baik.

Sifat kualitatif bangsa ternak adalah penentuan dalam karakter ternak dimana individu-individu dapat di klasifikasikan ke dalam satu dari dua kelompok atau lebih ternak, dan pengelompokan ini berbeda jelas satu sama lainnya. Sifat kualitatif ini dapat didasarkan penampakan yang tidak dapat diukur dan sedikit atau bahkan tidak ada hubungannya dengan kemampuan produksi. Sifat kualitatif yang dimiliki oleh individu ternak di antaranya adalah warna tubuh, bentuk dan panjang telinga, dan berdasarkan genetisnya sifat kualitatif di tentukan oleh banyak gen.

Beternak babi merupakan peluang yang sangat menguntungkan bagi masyarakat kecamatan Atambua Selatan kabupaten Belu yakni sebagai sumber penghasilan keluarga dan pemenuhan kebutuhan protein hewani masyarakat. Dengan data populasi ternak babi pada tahun 2015 yaitu 58.649 ekor, namun data populasi saja tidak dapat memberikan gambaran tentang tingkat produksi ternak babi.

\section{Metode}

Penelitian ini dilaksanakan pada bulan April sampai dengan bulan Mei 2016 di kecamatan Atambua Selatan kelurahan Fatukbot dan Kelurahan Manuaman Kabupaten Belu. Ternak yang digunakan dalam penelitian ini adalah ternak babi jantan milik peternak sebagai sampel sebanyak 349 ekor yang terdiri dari babi jantan lokal 250 ekor dan Peranakan VDL 99 ekor. Alat yang di gunakan dalam penelitian ini adalah buku tulis, pena, kuesioner, pita ukur, tongkat ukur dan timbangan ternak. Penafsiran umur berdasarkan perkembangan dan pergantian gigi seri serta terasahnya gigi seri (permanen) (Poespa, 1996). Pengelompokan umur terdiri dari :

1. Kelompok I jantan sepasang gigi seri (umur 0,5-1 tahun) kelompok anak.

2. Kelompok II jantan gigi seri tetap 2-4 ( $\geq 1-2$ tahun) kelompok muda.

3. Kelompok III jantan gigi seri tetap 6-8 (umur $\geq 2-4)$ kelompok dewasa.

Responden yang digunakan dalam penelitian ini adalah 156 peternak babi yang memiliki ternak babi jantan minimal 3 ekor dan lama beternak minimal 3 tahun. Berdasarkan hasil survei awal jumlah peternak di kelurahan Fatukbot 315 orang sehingga diambil sampel 94 orang yakni $30 \%$ dari populasi, sedangkan di kelurahan Manuaman jumlah peternak 207 orang sehingga di ambil sampel 62 orang yakni 30\% dari populasi yang ada dua kelurahan tersebut.

Penelitian ini menggunakan Metode survei. Teknik pengambilan sampel dilakukan dengan cara Simple Purposive Sampling (Sudjana, 2002) yaitu untuk menentukan wilayah penelitian, sedangkan untuk menentukan ternak yang digunakan sebagai sampel dilakukan dengan cara Simple Random Sampling Penelitian ini didasarkan atas beberapa kriteria antara lain kelurahan yang memiliki populasi ternak babi terbanyak serta dapat dijangkau dengan sarana transportasi sehingga diperoleh 2 kelurahan yaitu Fatukbot dan Manuaman dari 4 kelurahan yang ada pada Kecamatan Atambua Selatan. Variabel yang diamati pada penelitian ini adalah:

a. Warna Bulu

Pengamatan dilakukan dengan melihat sifat fisik yang tampak, berdasarkan warna bulu digolongkan menjadi 5, yakni: putih, hitam, cokelat atau kemerah-merahan, berselempang (belted) dan bercak-bercak (spotted).

b. Bobot Badan

Pengamatan yang dilakukan menggunakan alat timbangan dalam satuan $\mathrm{kg}$. c. Panjang Telinga

Pengamatan dilakukan dengan mengukur jarak antara ujung telinga sampa pangkal telinga bagian dalam. Dapat diukur dengan penggaris atau pita ukur.

d. Panjang Badan

Adalah pengamatan yang dilakukan dengan mengukur jarak garis lurus dari ujung tertinggi sampai ujung tulang ekor paling belakang.

e. Lingkar Dada

Pengamatan yang dilakukan dengan mengukur lingkar rongga dada melalui sendi bahu menggunakan pita ukur dalam satuan $\mathrm{cm}$

f. Tinggi Pundak

Pengamatan yang dilakukan dengan mengukur jarak tertinggi pundak sampai tanah, diukur dengan menggunakan tongkat ukur dalam $\mathrm{cm}$.

Data yang diperoleh dalam penelitian ini dianalisis dengan menggunakan analisis statistika deskriptif yaitu menghitung Nilai rata-rata dari masing-masing variabel, Standar Deviasi dan Koefisien Keragaman untuk menganalisis data yang telah dikumpulkan sesuai petunjuk Gujarati \& Porter (2009).

\section{Hasil dan Pembahasan}

\subsection{Gambaran Umum Lokasi Penelitian}

Atambua selatan merupakan salah satu kecamatan yang ada di kota Atambua Kabupaten Belu, Nusa Tengara Timur. Kecamatan ini merupakan pusat kegiatan kemasyarakatan di kota Atambua yang secara geografisnya memiliki luas wilayah mencapai $\pm 15.73 \mathrm{~km}^{2}$ dan dengan jumlah penduduk mencapai \pm 23.357 jiwa. Memiliki 4 kelurahan yakni Kelurahan Fatukbot, Kelurahan Lidak, Kelurahan Manuaman dan Kelurahan Rinbesi dengan populasi ternak pada tahun 2015 berjumlah 2.176 ekor. Usaha beternak babi di anggap sebagai usaha sampingan oleh sebagian peternak dan ada pula sebagai satu-satunya mata pencahariannya

Berdasarkan pengamatan dan wawancara, masih banyaknya peternak di lokasi penelitian menggunakan kandang untuk ternak babi dengan keadaan yang tidak sesuai dengan kebutuhan yakni menggunakan kayu ataupun bambu dan beberapa peternak sudah menggunakan lantai semen pada kandangnya, sebagian juga menggunakan besi untuk dindingnya serta atap kandang menggunakan daun gewang dan alang-alang namun umumnya sudah menggunakan seng. Ventilasi udara terjadi secara alami melalui dinding kandang yang sengaja dibuat setengah bangunan dengan diberi jarak yang cukup untuk keluar masuknya udara. Keadaan kandang yang kotor, lantai tidak datar dan berlubang menyebabkan ternak babi lokal yang ada di daerah tersebut tidak nyaman dan berakibat pada menurunnya produktivitas. Secara umum kandang ternak babi harus dalam keadaan bersih, lantai datar dan tidak berlubang, mempunyai saluran pembuangan kotoran, dekat dengan sumber air agar dalam pemeliharaan dapat memudahkan dalam pembersihan dan pemberian air 
minum. Oleh karena itu, dapat diduga bahwa kandang yang tidak sesuai untuk ternak babi lokal di Kecamatan Atambua Selatan ini dapat menjadi salah satu faktor penyebab pertumbuhan dan perkembangan produktivitas ternak babi rendah. Di Kecamatan Atambua selatan sistem pemeliharaan yang dipakai sebagian besar masyarakatnya adalah bersifat intensif atau dikandangkan. Di lokasi penelitian jenis kandang dalam bentuk kelompok atau individu sesuai dengan jenis kelamin dan kelompok umur.

Dari hasil pengamatan dan hasil wawancara yang telah dilakukan data menunjukkan bahwa $64 \%$ masyarakat tidak memiliki lahan untuk pakan ternak kemudian membeli pakan sendiri, $16 \%$ masyarakat memiliki lahan untuk pakan ternaknya seperti singkong, batang pisang, batang jagung dan $20 \%$ masyarakat lainnya memilih menggunakan hasil ikutan saat panen tiba.

Makanan pokok yang biasanya diberikan adalah jagung giling dan dedak, sisa limbah rumah tangga maupun rumah makan, ampas tahu, batang pisang dan terkadang pula ternak diberikan hijauan seperti lamtoro sebagai tambahan saja Frekuensi pemberian pakan ternak ini dalam sehari rata-rata peternak memberi makan sekaligus minum 2 kali dengan tidak menggunakan ukuran yang sama saat pemberian makan, ternak selalu diberikan makanan setiap pagi dan sore.

Dalam segitiga ilmu peternakan suatu usaha yang baik harus berada dalam jalur segitiga ini yaitu pakan, perkandangan dan salah satunya adalah kesehatan ternak yang merupakan faktor utama agar usaha yang kita jalani tidak sia-sia Kesehatan dalam hal ini kebersihan kandang, kebersihan ternak babi, pencegahan dan pengobatan penyakit pada ternak babi. Semua ternak babi di lokasi penelitian berada dalam kandang namun kebersihan kandang kurang begitu diperhatikan sehingga kandang biasanya dalam sehari dibersihkan 1 kali pada saat ternak babi dimandikan atau dibersihkan karena kandang ternak berada tidak jauh dari perumahan peternak makan pengontrolan dan pencegahan selalu dilakukan. Sesuai dengan hasil penelitian dan wawancara yang dilakukan sebagian besar peternak mengeluhkan ternak babi yang terkena penyakit $66,38 \%$ masyarakat menghubungi petugas dari Dinas Peternakan untuk di obati, dan 21,59\% memilih untuk menanganinya sendiri dan sisanya $12,82 \%$ masyarakat memilih untuk dibiarkan saja tanpa penanganan dari pihak mana pun. Masih banyak pula masyarakat yang memilih untuk ternaknya tidak divaksin karena banyak yang beranggapan bahwa vaksin yang diberikan oleh Dinas Peternakan dapat membahayakan ternaknya namun sebagian orang dengan pikiran yang maju lebih memilih ternaknya untuk divaksin agar terhindar dari berbagai serangan penyakit, vaksin yang banyak diberikan oleh petugas Dinas Peternakan adalah vaksin Hocholera yang diberikan secara gratis.

\subsection{Warna Bulu}

Pengamatan warna bulu pada babi lokal jantan di Kecamatan Atambua Selatan Kabupaten Belu, Provinsi Nusa Tenggara Timur tidak menggunakan pengukuran, melainkan pengamatan secara langsung terhadap warna ternak babi tersebut. (Hardjosubroto, 1994), menyatakan bahwa sifat kualitatif (warna bulu) tidak dapat diukur atau dihitung tetapi hanya dapat dikelompokkan secara tegas. Warna bulu pada ternak babi lokal yang menjadi objek penelitian ini umumnya memiliki bulu yang berwarna hitam pekat dan tebal di seluruh tubuh ternak, sebagian pula memiliki warna bercak putih-hitam, cokelat bercak hitam-putih. Soewandi \& Thalib (2015) menyatakan bahwa warna bulu babi Timor adalah dominan hitam, diikuti belang putih, putih dan merah bata. Babi lokal yang terdapat didaerah Kecamatan Atambua Selatan ini dapat digolongkan ke dalam jenis babi lokal asli Timor, hal ini mengacu pada adanya kesamaan ciri-ciri sifat kualitatif antara babi lokal asli Timor dengan babi lokal yang ada. Ciri-ciri ternak babi lokal Timor yang dipelihara adalah; bentuk badan sedang; kepala kecil, agak panjang dengan taring yang tidak terlalu mencuat apabila dewasa; telinga kecil, sedikit tegak; tulang belakang lemah sehingga terkadang perut hampir menyusur tanah terutama pada babi yang gemuk atau induk bunting; warna bulu bervariasi hitam, belang hitam atau kehitam-hitaman, putih, merah-coklat; keadaan bulu kasar terutama sepanjang garis punggung; kaki pendek, moncong runcing, gerakan lincah (Pasaribu, 2015)

Pengamatan warna bulu pada ternak babi Peranakan VDL di Kecamatan Atambua Selatan umumnya memiliki warna putih yang disertai bulu yang halus di seluruh tubuh ternak dan sebagian adanya bercak-bercak hitam pada bagian tubuhnya dan pada daerah lubang hidung babi ini berwarna putih dan berlendir. Ternak babi Peranakan VDL yang ada di lokasi penelitian memiliki ciri kepala besar agak panjang, telinga besar panjang, setengah bergantung ke muka sejajar dengan kepala, tulang belakang panjang, leher hampir bulat, dan badan besar.

\subsection{Bobot Badan}

Bobot badan merupakan bobot yang di dapatkan selama ternak dipelihara dan di dalam keadaan hidup (Natasasmita \& Mudikdjo, 1979). Pengukuran bobot badan merupakan salah satu pengukuran yang digunakan untuk mengetahui sifat kuantitatif pada tubuh ternak dengan menggunakan timbangan digital berkapasitas $\geq 200 \mathrm{~kg}$. Rata-rata, standar deviasi dan koefisien keragaman bobot badan babi jantan lokal untuk semua kelompok umur seperti pada Tabel 1

Rata-rata setiap bobot badan ternak babi jantan lokal untuk setiap kelompok umur yaitu: Jantan Anak 7,66 kg $\pm 5,5 \mathrm{~kg}$; Jantan Muda 28,59 kg $\pm 25,77 \mathrm{~kg}$ dan jantan Dewasa $111,00 \mathrm{~kg} \pm 18,25 \mathrm{~kg}$. Ternak babi lokal dengan ukuran tubuh lebih besar mencerminkan kualitas pertumbuhan yang baik dibanding dengan ternak babi lain pada umur yang sama. Data tentang rata-rata, standar deviasi dan koefisien keragaman bobot badan dan ukuran linear tubuh babi jantan lokal (babi Timor) pada pola peternakan rakyat belum pernah diteliti sehingga tidak ada data pembanding dengan data penelitian ini.
Tabel 1. Rata-rata, Standar Deviasi dan Koefisien Keragaman Bobot Badan ternak babi jantan Lokal di Kec. Atambua Selatan

\begin{tabular}{cccc}
\hline Kelompok umur & $\bar{X}(\mathrm{~cm})$ & SD & KK $(\%)$ \\
\hline Anak & 7,66 & 5,56 & 72,54 \\
Muda & 28,59 & 25,77 & 90,13 \\
Dewasa & 111,00 & 18,25 & 16,44 \\
\hline
\end{tabular}

Standar deviasi merupakan suatu nilai yang menunjukkan tingkat variasi suatu kelompok data. Standar deviasi bobot badan tenak babi jantan lokal masing-masing adalah 5,5;25,77;18,25 terlihat bahwa standar deviasi bobot badan ternak babi jantan muda lebih besar daripada jantan anak dan jantan dewasa. Hal ini menunjukkan bahwa ternak jantan lokal muda memiliki variabilitas yang lebih tinggi, hal ini didukung oleh pendapat Aunudin (1989) yang menyatakan bahwa standar deviasi dan varians baku merupakan variasi sebaran data, semakin kecil nilai sebarannya berarti variasi nilai data semakin sama.

Dari hasil penelitian menunjukkan bahwa koefisien keragaman atau variasi populasi ternak babi jantan lokal dari semua kelompok umur adalah anak $72,54 \%$, muda $43,98 \%$, dewasa $16,44 \%$ maka nilai koefisien terbaik dimiliki oleh ternak jantan lokal dewasa karena memiliki nilai koefisien yang lebih kecil daripada ternak lokal jantan anak dan jantan muda. Koefisien Keragaman kelompok umur anak lebih besar dari kelompok umur muda dan dewasa karena kelompok umur anak masih dalam pengawasan penuh oleh induk lain halnya bila telah lepas sapih, karena ada pengaruh lingkungan seperti makanan atau pengaruh induk(air susu induk) hal ini didukung oleh pendapat (Warwick et al. 1990) yang menyatakan bahwa makanan dan umur induk berpengaruh terhadap berat badan anak.

Bobot badan merupakan salah satu indikator pertumbuhan ternak. Ratarata, standar deviasi dan koefisien keragaman bobot badan ternak babi jantan Peranakan VDL terdapat dalam Tabel 2 .

Tabel 2. Rata-rata, Standar Deviasi dan Koefisien Keragaman Bobot Badan ternak babi jantan Peranakan VDL di Kec. Atambua Selatan.

\begin{tabular}{cccc}
\hline Kelompok umur & $\bar{X}(\mathrm{~cm})$ & SD & KK $(\%)$ \\
\hline Anak & 11,79 & 8,37 & 70,97 \\
Muda & 78,31 & 11,53 & 14,72 \\
Dewasa & 131,60 & 23,97 & 18,22 \\
\hline
\end{tabular}

Rata-rata setiap bobot badan ternak babi jantan Peranakan VDL untuk setiap kelompok umur di Kecamatan Atambua Selatan yaitu Jantan Anak 11,79 kg \pm $8,37 \mathrm{~kg}$, Jantan Muda 78,31 kg $\pm 11,53 \mathrm{~kg}$ dan jantan Dewasa 131,60 kg $\pm 23,97$ $\mathrm{kg}$. Hana et al., (2016) melaporkan bahwa rataan bobot badan ternak babi PVDL kelompok umur jantan Anak 3,74 kg $\pm 1,60 \mathrm{~kg}$, Jantan Muda 24,2 kg \pm 7,70 kg dan jantan Dewasa 98,02 kg $\pm 31,99 \mathrm{~kg}$. Rata-rata bobot badan ternak babi Peranakan VDL untuk semua kelompok umur dalam penelitian ini lebih tinggi dari penelitian sebelumnya, karena jenis pemeliharaan dan lingkungan yang berbeda. Performans atau penampilan ternak tergantung pada lingkungan dimana ternak tersebut berada selain faktor genetik (Hardjosubroto, 1994).

Standar deviasi bobot badan tenak babi jantan Peranakan VDL masingmasing adalah 8,37:11,53:23,97 terlihat bahwa nilai standar deviasi bobot badan ternak babi Peranakan VDL jantan dewasa lebih besar daripada jantan anak dan jantan muda. Hal ini menunjukkan bahwa ternak jantan Peranakan VDL dewasa memiliki variabilitas yang lebih tinggi. Dibandingkan dengan penelitian sebelumnya pada daerah yang berbeda dapat dilihat standar deviasi yang dimiliki oleh semua kelompok umur 1,60: 7,70:31,99 (Hana et al., 2016) maka dapat di simpulkan bahwa penelitian ini memiliki nilai Variabilitas yang tinggi pada kelompok umur anak dan muda dibandingkan penelitian sebelumnya, kelompok umur anak dan muda memiliki nilai yang lebih tinggi namun pada kelompok umur dewasa memiliki variabilitas rendah dibandingkan dengan penelitian sebelumnya. Perbedaan nilai variabilitas sifat seekor ternak tergantung pada populasi dan waktu pemeliharaan (Warwick et al., 1990)

Menurut Gujarati \& Porter (2009) menyatakan bahwa semakin kecil nilai Koefisien keragaman atau variasi sebuah populasi menujukan kualitas sifa populasi yang lebih baik karena memiliki tingkat keragaman yang lebih rendah. Dari hasil penelitian menunjukkan bahwa koefisien keragaman atau variasi populasi ternak jantan Peranakan VDL dari semua kelompok umur adalah anak $70,97 \%$, muda $14,72 \%$, dewasa $18,22 \%$ nilai koefisien terbaik dalam penelitian ii dimiliki oleh ternak jantan Peranakan VDL muda karena memiliki nilai koefisien yang lebih kecil daripada ternak lokal jantan anak dan jantan dewasa. Dibandingkan dari data penelitian sebelumnya dapat dilihat bahwa koefisien keragaman dari semua kelompok umur adalah 42,8\%, 31,82\%, 32,64\% (Hana et al., 2016), nilai koefisien keragaman dalam penelitian ini pada kelompok umur anak memiliki nilai yang lebih tinggi dari penelitian sebelumnya namun berbeda dengan kelompok umur Muda dan Dewasa keduanya memiliki nilai keragaman variasi yang rendah karena memiliki nilai yang lebih kecil dari penelitian sebelumnya. Perbedaan nilai koefisien keragaman antara penelitian ini dengan penelitian sebelumnya karena adanya perbedaan lingkungan. Hardjosubroto (1994) menyatakan bahwa pengaruh faktor lingkungan terhadap individu satu dengan individu lain tidak akan sama sehingga menyebabkan adanya variasi tampilan ternak. 


\subsection{Panjang Telinga}

Ukuran panjang telinga di pakai untuk menentukan ciri suatu bangsa ternak. Rata-rata, standar deviasi dan koefisien keragaman panjang telinga babi lokal jantan dapat dilihat dalam Tabel 3.

Tabel 3. Rata-rata, Standar deviasi, dan Koefisien keragaman Panjang Telinga ternak babi jantan lokal di Kec. Atambua Selatan.

\begin{tabular}{cccc}
\hline Kelompok umur & $\bar{X}(\mathrm{~cm})$ & SD & KK $(\%)$ \\
\hline Anak & 8,26 & 3,01 & 36,40 \\
Muda & 11,42 & 2,27 & 19,90 \\
Dewasa & 20,44 & 1,85 & 9.04 \\
\hline
\end{tabular}

Rata-rata setiap panjang telinga ternak babi jantan lokal untuk setiap kelompok umur di Kecamatan Atambua Selatan yaitu Jantan Anak $8,26 \mathrm{~cm} \pm$ $3,01 \mathrm{~cm}$, Jantan Muda 11,42 cm $\pm 2,27 \mathrm{~cm}$ dan jantan Dewasa 20,44 $\mathrm{cm} \pm 1,85$ $\mathrm{cm}$.

Standar deviasi panjang telinga tenak babi jantan lokal masing-masing adalah jantan anak 3,01: jantan muda 2,27: jantan dewasa 1,85 terlihat bahwa standar deviasi pajang telinga ternak babi jantan lokal anak lebih besar daripada jantan muda. Hal ini menunjukkan bahwa ternak jantan lokal anak memiliki variabilitas yang lebih tinggi, perbedaan nilai variabilitas sifat seekor ternak tergantung pada populasi dan waktu pemeliharaan (Warwick et al., 1990)

Dari hasil analisis menunjukkan bahwa koefisien keragaman atau varias populasi ternak jantan lokal dari semua kelompok umur adalah anak 36,40\%, muda $19,90 \%$, dewasa $9,04 \%$ maka nilai koefisien terbaik dimiliki oleh ternak jantan lokal dewasa karena memiliki nilai koefisien keragaman yang lebih kecil daripada ternak lokal jantan anak dan jantan muda. Performans atau penampilan ternak tergantung pada lingkungan dimana ternak tersebut berada selain faktor genetik (Hardjosubroto, 1994).

Panjang telinga seekor ternak tidak ada kaitannya dengan nilai ekonomis dari seekor ternak namun dapat menggambarkan ciri dari satu bangsa ternak. Nilai rata-rata, standar deviasi dan koefisien keragaman panjang telinga babi Peranakan VDL dapat dilihat dalam Tabel 4.

Tabel 4. Rata-rata, Standar Deviasi dan Koefisien Keragaman panjang Telinga ternak babi jantan Peranakan VDL di Kec. Atambua Selatan

\begin{tabular}{cccc}
\hline Kelompok umur & $\bar{X}(\mathrm{~cm})$ & SD & KK $(\%)$ \\
\hline Anak & 10,69 & 4,30 & 40,27 \\
Muda & 12,79 & 2,01 & 15,73 \\
Dewasa & 21,61 & 2,56 & 11,86 \\
\hline
\end{tabular}

Rata-rata setiap panjang telinga ternak babi jantan PVDL untuk setiap kelompok umur di Kecamatan Atambua Selatan yaitu Jantan Anak $10,69 \mathrm{~cm}$ $\pm 4,30 \mathrm{~cm}$, Jantan Muda 12,79 $\mathrm{cm} \pm 2,01 \mathrm{~cm}$ dan jantan Dewasa 21,61 cm $\pm 2,56$ $\mathrm{cm}$. Standar deviasi panjang telinga tenak babi jantan Peranakan VDL masingmasing adalah jantan anak, muda, dewasa yakni 4,30: 2,01: 2,56 dar perbandingan data ini bahwa standar deviasi panjang telinga ternak babi jantan Peranakan VDL kelompok umur Muda lebih besar daripada jantan anak dan jantan Dewasa. Hal ini menunjukkan bahwa ternak babi jantan Peranakan VDL kelompok umur anak memiliki variabilitas yang lebih tinggi. Dari hasil analisis menunjukkan bahwa koefisien keragaman atau variasi populasi ternak jantan Peranakan VDL dari semua kelompok umur adalah anak 40,27\%, Muda $15,73 \%$, Dewasa $11,86 \%$, maka nilai koefisien terbaik dimiliki oleh ternak jantan Peranakan VDL dewasa karena memiliki nilai koefisien keragaman yang lebih kecil daripada ternak babi Peranakan VDL jantan anak dan jantan muda.

\subsection{Panjang Badan}

Panjang badan adalah salah satu bentuk ukuran linear tubuh seekor tenak yang dapat digunakan untuk mengetahui pertambahan berat badan. Rata-rata, standar deviasi dan koefisien keragaman panjang badan babi jantan lokal terdapat dalam Tabel 5.

Tabel 5. Rata-rata, Standar deviasi, dan Koefisien keragaman Panjang badan ternak babi jantan lokal di Kec. Atambua Selatan.

\begin{tabular}{cccc}
\hline Kelompok umur & $\bar{X}(\mathrm{~cm})$ & SD & KK $(\%)$ \\
\hline Anak & 36,30 & 10,96 & 30,21 \\
Muda & 46,52 & 12,81 & 27,53 \\
Dewasa & 107,67 & 12,12 & 11,26 \\
\hline
\end{tabular}

Rata-rata Panjang badan ternak babi jantan lokal untuk setiap kelompok umur di Kecamatan Atambua Selatan yaitu Anak $36,30 \mathrm{~cm} \pm 13,95 \mathrm{~cm}$, Muda $46,56 \mathrm{~cm} \pm 12,81 \mathrm{~cm}$ dan Dewasa 107,67 $\mathrm{cm} \pm 12,12 \mathrm{~cm}$.

Dari hasil analisis menunjukkan bahwa standar deviasi panjang badan ternak jantan lokal pada Kecamatan Atambua Selatan masing-masing kelompok umur yakni anak 10,96: muda 12:81: dewasa 12,12. Standar deviasi panjang badan ternak babi lokal jantan muda lebih besar daripada kelompok umur jantan anak dan dewasa. Kenyataan ini menunjukkan bahwa ternak babi lokal jantan muda memiliki variabilitas yang lebih tinggi dan data di antara elemen heterogen atau tidak sama.
Koefisien Keragaman atau variasi panjang badan ternak babi jantan lokal kelompok umur anak, muda dan dewasa dalam penelitian ini adalah $30,21 \%$, $27,53 \%$, dan $11,26 \%$. Nilai koefisien keragaman panjang badan terbaik di miliki oleh ternak babi jantan lokal dewasa karena memiliki nilai keragaman yang lebih kecil dibanding jantan anak dan jantan muda. Perlakuan pemeliharaan ternak babi lokal yang berbeda antara peternak merupakan salah satu faktor penyebab perbedaan ukuran-ukuran tubuh antara kelompok ternak. Pemberian pakan dengan menggunakan limbah hasil pertanian juga dapat menimbulkan keragaman sifat ternak, dimana jenis vegetasi (hasil pertanian) yang relatif berbeda antara setiap Kelurahan.

Panjang badan dapat dijadikan salah satu indikator pertumbuhan tulang ternak. Rata-rata, standar deviasi dan koefisien keragaman babi jantan peranakan VDL dapat dilihat dalam Tabel 6.

Tabel 6. Rata-rata, Standar Deviasi dan Koefisien Keragaman panjang Badan ternak babi jantan Peranakan VDL di Kec. Atambua Selatan

\begin{tabular}{cccc}
\hline Kelompok umur & $\bar{X}(\mathrm{~cm})$ & SD & KK $(\%)$ \\
\hline Anak & 39,23 & 13,95 & 35,56 \\
Muda & 63,21 & 13,10 & 20,71 \\
Dewasa & 108,94 & 11,50 & 10,55 \\
\hline
\end{tabular}

Rata-rata setiap panjang badan ternak babi jantan Peranakan VDL untuk setiap kelompok umur di Kecamatan Atambua Selatan yaitu Jantan Anak $39,23 \mathrm{~cm} \pm 13,95 \mathrm{~cm}$, Jantan Muda 63,21 $\mathrm{cm} \pm 13,10 \mathrm{~cm}$ dan jantan Dewasa $108,94 \mathrm{~cm} \pm 11,50 \mathrm{~cm}$. Jika di bandingkan dengan penelitian sebelumnya dengan variabel yang sama namun di daerah yang berbeda dapat dilihat bahwa rata-rata panjang badannya kelompok umur anak, muda dan dewasa adalah 18,09 $\mathrm{cm}$, $33,74 \mathrm{~cm}, 75,52 \mathrm{~cm}$ (Hana et al., 2016) maka dapat di simpulkan bahwa nilai rataan pada penelitian ini lebih tinggi dibandingkan dengan nilai rataan pada penelitian sebelumnya. Perbedaan ini diduga disebabkan oleh perbedaan lingkungan, antara lain perbedaan jenis dan volume pakan yang berbeda. Jumlah dan jenis pakan yang dikonsumsi oleh seekor ternak berpengaruh terhadap performansi seekor ternak, hal ini sesuai dengan pendapat Wahyu (1997) yang menyatakan bahwa faktor penting yang berperan dalam produksi seekor ternak adalah pakan.

Standar deviasi merupakan suatu nilai yang menunjukkan tingkat variasi suatu kelompok data. Standar deviasi panjang badan tenak babi jantan Peranakan VDL masing-masing adalah jantan anak, muda, dewasa yakni 13,95:13,10: 11,50 dari perbandingan data standar deviasi panjang badan ternak babi jantan Peranakan VDL kelompok umur anak lebih besar daripada jantan muda dan jantan Dewasa. Hal ini dapat disimpulkan bahwa ternak babi jantan Peranakan VDL kelompok umur anak memiliki variabilitas yang lebih tinggi. Hana et al. (2016) melaporkan bahwa standar deviasi panjang badan babi jantan Peranakan VDL untuk kelompok umur anak, muda dan dewasa berturut-turut adalah: 2,3:7,97:11,82. Perbedaan nilai standar deviasi panjang badan ini disebabkan karena perbedaan populasi yang diukur. Astuti (2007) menyatakan bahwa besarnya nilai standar deviasi suatu sifat tergantung pada populasi ternak.

Dari hasil penelitian menunjukkan bahwa koefisien keragaman atau variasi populasi ternak jantan Peranakan VDL dari semua kelompok umur adalah anak $35,56 \%$, Muda $20,71 \%$, Dewasa $10,55 \%$, maka nilai koefisien terbaik dimiliki oleh ternak jantan Peranakan VDL dewasa karena memiliki nilai koefisien keragaman yang lebih kecil daripada ternak babi Peranakan VDL jantan anak dan jantan muda. Bila membandingkan dengan penelitian sebelumnya bahwa Koefisien Keragaman ternak babi Peranakan VDL jantan dari berbagai kelompok umur yaitu $11,77 \%, 23,56 \%$, dan $15,65 \%$ maka dapat disimpulkan bahwa koefisien keragaman ternak Babi Peranakan VDL pada kelompok umur Dewasa memiliki nilai koefisien keragaman yang kecil daripada penelitian sebelumnya populasi dan sistem pemeliharaan sehingga memiliki . Keseragaman ukuranukuran tubuh individu ternak babi sangat peka terhadap pengaruh lingkungan, keseragaman ini muncul dipengaruhi oleh beberapa faktor, yaitu kondisi pemeliharaan, pengaruh pemberian pakan, kondisi alat pencernaan dan keragaman genetik (Mulliadi, 1996). Ternak babi lokal dengan ukuran tubuh lebih besar mencerminkan kualitas pertumbuhan yang baik dibanding dengan ternak babi lain pada umur yang sama.

\subsection{Lingkar Dada}

Lingkar dada adalah salah satu indikator yang dapat digunakan untuk menentukan pertumbuhan bobot badan ternak. Lingkar dada diukur dari belakang bahu sampai bagian bawah di belakang kaki depan melingkar. Nilai rata-rata, standar deviasi dan koefisien keragaman lingkar dada babi jantan Peranakan VDL untuk semua kelompok umur dapat dilihat dalam Tabel 7.

Tabel 7. Rata-rata, Standar deviasi, dan Koefisien keragaman Lingkar Dada ternak babi jantan lokal di Kec. Atambua Selatan.

\begin{tabular}{cccc}
\hline Kelompok umur & $\bar{X}(\mathrm{~cm})$ & SD & KK $(\%)$ \\
\hline Anak & 36,34 & 10,72 & 29,50 \\
Muda & 45,80 & 11,31 & 24,69 \\
Dewasa & 94,91 & 19,97 & 21,36 \\
\hline
\end{tabular}

Rata-rata setiap lingkar dada ternak babi jantan lokal untuk setiap kelompok umur di Kecamatan Atambua Selatan yaitu Jantan Anak 36,34 cm $\pm 10,72 \mathrm{~cm}$, 
Jantan Muda 45,80 cm $\pm 11,31 \mathrm{~cm}$ dan jantan Dewasa 94,91 cm \pm 19,97. Standar deviasi lingkar dada tenak babi jantan lokal masing-masing adalah 10,72:11,31:19,97 terlihat bahwa standar deviasi lingkar dada ternak babi jantan dewasa lebih besar daripada jantan anak dan jantan muda.

Dari hasil penelitian menunjukkan bahwa koefisien keragaman atau variasi populasi ternak jantan lokal dari semua kelompok umur adalah anak $29,50 \%$, muda $24,69 \%$, dewasa $21,36 \%$ maka nilai koefisien terbaik dimiliki oleh ternak jantan lokal dewasa karena memiliki nilai koefisien keragaman yang lebih kecil daripada ternak lokal jantan anak dan jantan muda. hal ini didukung oleh pendapat (Gujarati \& Porter, 2009) yang menyatakan bahwa semakin kecil nilai Koefisien keragaman atau variasi sebuah populasi menujukan kualitas sifat populasi yang lebih tinggi karena memiliki tingkat keragaman yang lebih rendah. Hal ini menunjukkan bahwa ukuran lingkar dada ternak didaerah penelitian hampir relatif seragam dengan ukuran lingkar dada yang cukup tinggi, semakin besar lingkar dada, organ-organ yang terdapat di dalam rongga dada juga semakin besar seperti paru-paru dan jantung (Santosa, 2008).

Lingkar dada adalah salah satu indikator yang dapat digunakan untuk menentukan bobot badan ternak. Lingkar dada diukur dari belakang bahu sampai bagian bawah di belakang kaki depan melingkar.

Tabel 8. Rata-rata, Standar deviasi, dan Koefisien Keragaman Lingkar Dada ternak babi Peranakan VDL di Kec. Atambua Selatan.

\begin{tabular}{cccc}
\hline Kelompok umur & $\bar{X}(\mathrm{~cm})$ & $\mathrm{SD}$ & $\mathrm{KK}(\%)$ \\
\hline Anak & 42,83 & 14,03 & 32,76 \\
Muda & 59,88 & 11,28 & 18,83 \\
Dewasa & 103,13 & 16,03 & 15,55 \\
\hline
\end{tabular}

Rata-rata setiap lingkar dada ternak babi jantan PVDL untuk setiap kelompok umur di Kecamatan Atambua Selatan yaitu Jantan Anak 42,83 cm $\pm 14,03 \mathrm{~cm}$, Jantan Muda 59,88 cm $\pm 11,28 \mathrm{~cm}$ dan jantan Dewasa $103,13 \mathrm{~cm} \pm$ $16,03 \mathrm{~cm}$. Jika di bandingkan dengan penelitian sebelumnya dengan variabel yang sama namun di daerah yang berbeda dapat dilihat bahwa rata-rata lingkar dada kelompok umur anak, muda dan dewasa adalah $36,28 \mathrm{~cm}, 56,85 \mathrm{~cm}$, $105,34 \mathrm{~cm}$ (Hana et al., 2016) maka dapat di simpulkan bahwa nilai rataan lingkar dada pada penelitian ini lebih rendah dibandingkan dengan nilai rataan lingkar dada pada penelitian sebelumnya di kelompok umur dewasa dan lebih tinggi di kelompok umur anak dan muda.

Standar deviasi merupakan suatu nilai yang menunjukkan tingkat variasi suatu kelompok data. Standar deviasi lingkar dada tenak babi jantan Peranakan VDL masing-masing kelompok umur adalah anak 59,88 : muda 11,28: dewasa 16,03 terlihat bahwa standar deviasi lingkar dada ternak babi jantan Peranakan VDL anak lebih besar daripada jantan muda dan dewasa. Hal ini menunjukkan bahwa ternak jantan Peranakan VDL anak memiliki variabilitas yang lebih tinggi, hal ini didukung oleh pendapat Aunudin (1989) yang menyatakan bahwa standar deviasi dan varians baku merupakan variasi sebaran data, semakin kecil nilai sebarannya berarti variasi nilai data semakin sama, jika sebarannya bernilai 0 (nol) maka nilai semua datanya adalah sama dan semakin besar nilai besarannya berarti data semakin bervariasi berbeda dengan hasil penelitian sebelumnya pada daerah yang berbeda yaitu 3,48: 11,60:22,22 dari berbagai kelompok umur anak, muda dan dewasa maka dapat dibandingkan bahwa standar deviasi ternak babi Peranakan VDL jantan pada penelitian sebelumnya memiliki nilai variabilitas yang rendah karena nilai dari standar deviasi panjang badannya lebih rendah maka dapat disimpulkan bahwa standar deviasi yang dimiliki oleh ternak jantan Peranakan VDL jantan Anak memilik nilai Variabilitas yang tinggi.

Dari hasil analisis data menunjukkan bahwa koefisien keragaman atau variasi pada populasi ternak jantan Peranakan VDL dari semua kelompok umur adalah anak $32,76 \%$, muda $18,83 \%$, dan Dewasa $15,55 \%$. Nilai koefisien Keragaman terbaik dimiliki oleh ternak jantan lokal dewasa karena memiliki nilai koefisien keragaman yang lebih kecil daripada ternak babi Peranakan VDL jantan anak dan jantan muda. Hal ini didukung oleh pendapat Supranto, (2000) yang menyatakan bahwa semakin kecil nilai Koefisien keragaman atau variasi sebuah populasi menujukan kualitas sifat populasi yang lebih baik karena memiliki tingkat keragaman yang lebih rendah. Bila membandingkan dengan penelitian sebelumnya bahwa Koefisien Keragaman ternak babi Peranakan VDL jantan dari berbagai kelompok umur yaitu 9,60\%, 20,40\%, dan 21,09\% (Hana, 2015) maka dapat di lihat bahwa koefisien keragaman ternak Babi Peranakan VDL pada berbagai kelompok umur nilai koefisien keragaman terkecil pada kelompok umur anak pada penelitian sebelumnya maka dapat disimpulkan bahwa nilai koefisien keragaman lingkar dada pada penelitian ini memiliki nilai keragaman yang besar daripada penelitian sebelumnya.

\subsection{Tinggi Pundak}

Tinggi pundak merupakan salah satu indikator bertambahnya ukuran tubuh atau bertumbuhnya seekor ternak yang biasanya diukur dari bahu sampai ujung kaki depan (menyentuh tanah). Rata-rata, standar deviasi dan koefisien keragaman ternak babi lokal jantan di jelaskan dengan Tabel 9.

Rata-rata tinggi pundak untuk setiap kelompok umur ternak babi jantan lokal yang ada di Kecamatan Atambua Selatan yakni anak $28,84 \mathrm{~cm} \pm 7,39 \mathrm{~cm}$, muda $36,26 \mathrm{~cm} \pm 8,15$ dan dewasa $62,71 \mathrm{~cm} \pm 13,37 \mathrm{~cm}$. Standar deviasi tinggi pundak ternak babi jantan lokal kelompok umur anak, muda dan dewasa di Kecamatan Atambua Selatan adalah 9,42:8,15:13,37. Dilihat dari perbandingan tersebut maka standar deviasi tinggi pundak ternak babi lokal jantan muda memiliki nilai yang lebih kecil dari anak jantan dan dewasa jantan, jantan dewasa memiliki nilai yang lebih tinggi dari jantan anak dan muda, maka ini dapat dinyatakan bahwa tinggi pundak ternak babi lokal jantan umur dewasa memiliki variabilitas yang lebih tinggi dan data di antara anggota elemen heterogen.

Tabel 9. Rata-rata, Standar deviasi, dan Koefisien keragaman Tinggi pundak ternak babi jantan lokal di Kec. Atambua Selat

\begin{tabular}{cccc}
\hline Kelompok umur & $\bar{X}(\mathrm{~cm})$ & SD & KK $(\%)$ \\
\hline Anak & 28,84 & 7,39 & 25,61 \\
Muda & 36,26 & 8,15 & 22,46 \\
Dewasa & 62,71 & 13,37 & 21,32 \\
\hline
\end{tabular}

Koefisien keragaman merupakan ukuran dispersi relatif yang digunakan untuk membandingkan variasi dua atau lebih kelompok data. Koefisien keragaman tinggi pundak ternak babi jantan lokal kelompok umur anak, muda dan dewasa adalah: $21,32 \%, 22,46 \%$ dan $25,61 \%$. Koefisien keragaman tinggi pundak terbaik dimiliki oleh ternak babi lokal jantan dewasa karena memiliki nilai koefisien yang lebih rendah dibanding jantan anak dan jantan dewasa dikarenakan perbedaan populasi dan sistem pemeliharaannya.

Tinggi pundak merupakan salah satu indikator bertambahnya ukuran tubuh atau bertumbuhnya seekor ternak yang biasanya diukur dari bahu sampai ujung kaki depan (menyentuh tanah). Rata-rata ,standar deviasi dan koefisien keragaman ternak babi jantan Peranakan VDL di jelaskan dengan Tabel 10.

Tabel 10. Rata-rata, Standar deviasi, dan Koefisien keragaman Tinggi pundak ternak babi jantan Peranakan VDL di Kec. Atambua Selatan.

\begin{tabular}{cccc} 
Kelompok umur & $\bar{X}(\mathrm{~cm})$ & SD & KK $(\%)$ \\
Anak & 30,74 & 9,42 & 30,65 \\
Muda & 51,27 & 8,90 & 17,35 \\
Dewasa & 71,84 & 14,58 & 20,30 \\
\hline
\end{tabular}

Rata-rata tinggi pundak untuk setiap kelompok umur ternak babi jantan Peranakan VDL yang ada di Kecamatan Atambua Selatan yakni anak $30,74 \mathrm{~cm}$ $\pm 9,42 \mathrm{~cm}$, muda $51,27 \mathrm{~cm} \pm 8,90$ dan dewasa $71,84 \mathrm{~cm} \pm 14,58 \mathrm{~cm}$ dengan membandingkan pada penelitian sebelumnya dapat dilihat bahwa rataannya yaitu anak $21,15 \mathrm{~cm} \pm 2,97 \mathrm{~cm}$, muda $36,99 \mathrm{~cm} \pm 6,95$ dan dewasa $78,89 \mathrm{~cm} \pm 1,0$ $\mathrm{cm}$ (Hana et al., 2016) maka dapat disimpulkan bahwa rataan pada penelitian ini memiliki nilai yang lebih tinggi pada kelompok umur anak dan muda namun lebih rendah pada kelompok umur dewasa. Perbedaan tinggi pundak pada kedua penelitian disebabkan karena perbedaan manajemen pemeliharaan yakni sistim pemberian pakan, pengendalian penyakit. Blakely \& Bade (1998) menyatakan bahwa perbedaan pola manajemen menyebabkan perbedaan produksi seekor ternak.

Standar deviasi tinggi pundak ternak babi jantan Peranakan VDL kelompok umur anak, muda dan dewasa di Kecamatan Atambua Selatan adalah 9,42: 8,90 : 14,58. Dilihat dari perbandingan tersebut maka standar deviasi tinggi pundak ternak babi jantan Peranakan VDL muda memiliki nilai yang lebih kecil dari anak jantan dan dewasa jantan, jantan dewasa memiliki nilai yang lebih tinggi dari jantan anak dan muda, maka ini dapat dinyatakan bahwa tinggi pundak ternak babi jantan Peranakan VDL kelompok umur dewasa memiliki variabilitas yang lebih tinggi dan data di antara anggota elemen heterogen. Jika dibandingkan dengan penelitian sebelumnya dengan nilai standar deviasi kelompok umur anak 2,97, Muda 6,95, dan dewasa 1,01 (Hana et al., 2016) maka dapat dikatakan bahwa standar deviasi pada penelitian ini memiliki nilai Variabilitas yang lebih baik pada semua kelompok umur karena memiliki nilai yang lebih besar daripada penelitian sebelumnya.

Koefisien keragaman merupakan ukuran dispersi relatif yang digunakan untuk membandingkan variasi dua atau lebih kelompok data. Koefisien keragaman tinggi pundak ternak babi jantan Peranakan VDL kelompok umur anak, muda, dan dewasa adalah : 30,65\%, $17,35 \%$ dan $20,30 \%$. Koefisien keragaman tinggi pundak terbaik dimiliki oleh ternak babi jantan Peranakan VDL Muda karena memiliki nilai koefisien yang lebih rendah dibanding jantan anak dan jantan dewasa. Fugon (2004) cit. Hana et al. (2016) menyatakan bahwa semakin kecil nilai koefisien keragaman sebuah populasi menunjukkan kualitas sifat populasi yang lebih baik karena memiliki tingkat keragaman yang lebih rendah dibanding dengan penelitian sebelumnya dengan variabel yang sama pada darah yang berbeda yaitu anak 14,04\%, Muda 18,79\%, dan dewasa 1,28\% (Hana et al., 2016) maka dapat di simpulkan koefisien keragaman atau variasi dari tinggi pundak ternak babi jantan Peranakan VDL pada penelitian ini memiliki nilai Koefisien keragaman yang lebih rendah pada kelompok umur muda sedangkan pada kelompok umur anak dan dewasa nilai keragamannya sangat besar maka semakin besar nilai keragamannya.

\section{Simpulan}

Warna bulu ternak babi jantan Lokal di Kecamatan Atambua Selatan pada umumnya memiliki warna bulu tebal yang berwarna hitam pekat dan tebal di seluruh tubuh ternak, sebagian pula memiliki warna bercak putih-hitam, kecokelatan bercak hitam-putih. Sedangkan warna bulu pada ternak babi jantan Peranakan VDL umumnya berwarna putih dengan bulu yang halus di seluruh tubuh. Hasil pengukuran sifat kuantitatif pada babi lokal jantan menunjukkan bahwa rata-rata bobot badan anak $7,66 \mathrm{~kg}$, muda $28,59 \mathrm{~kg}$, dan dewasa 111,00 
$\mathrm{kg}$, pajang telinga anak $8,26 \mathrm{~cm}$, muda $11,42 \mathrm{~cm}$ dan dewasa $20,44 \mathrm{~cm}$, panjang badan anak $7,66 \mathrm{~cm}$, muda $28,59 \mathrm{~cm}$, dan dewasa $111,00 \mathrm{~cm}$, lingkar dada anak $36,30 \mathrm{~cm}$, muda $46,56 \mathrm{~cm}$, dewasa $107,67 \mathrm{~cm}$ dan tinggi pundak anak $28,84 \mathrm{~cm}$, muda $36,36 \mathrm{~cm}$, dewasa $62,71 \mathrm{~cm}$. Hasil pengukuran sifat kuantitatif pada ternak babi jantan peranakan VDL menunjukkan bahwa rata-rata bobot badan anak $11,79 \mathrm{~kg}$, muda $78,31 \mathrm{~kg}$ dan dewasa $131,60 \mathrm{~kg}$, panjang telinga anak 10,69 $\mathrm{cm}$, muda $12,79 \mathrm{~cm}$, dan dewasa $21,61 \mathrm{~cm}$, panjang badan anak $32,23 \mathrm{~cm}$, muda $63,21 \mathrm{~cm}$, dan dewasa $108,94 \mathrm{~cm}$, lingkar dada anak $42,83 \mathrm{~cm}$, muda $59,88 \mathrm{~cm}$ dan dewasa $103,13 \mathrm{~cm}$, tinggi pundak adalah anak $30,74 \mathrm{~cm}$, muda $51,27 \mathrm{~cm}$ dan dewasa $71,84 \mathrm{~cm}$.

\section{Pustaka}

Astuti, M. 2007. Pengantar Ilmu Statistik untuk Peternakan dan Kesehatan. Hewan. Cetakan pertama. Bogor: Binasti Publisher.

Aunudin. 1989. Analisis data. Jakarta: Gramedia Umum.

Blakely, J., dan Bade, D. H. 1998. Ilmu Peternakan, Edisi ke Empat. Penerjemah: Srigandono, B. Yogyakarta: Gadjah Mada University Press.

Gujarati, D.N. \& Porter, D.C. 2009. Basic Econometrics. McGraw-Hill Irwin.

Hana, M., Beyleto, V. \& Nurwati, M. 2016. Penampilan Produksi Babi Jantan Peranakan VDL dari Berbagai Kelompok Umur di Kecamatan Kota Kefamenanu, Kabupaten Timor Tengah Utara. JAS, 1(01): 17-19.

Hardjosubroto, W. 1994. Aplikasi Pemuliabiakan Ternak di Lapangan. Jakarta: PT. Gramedia Widiasarana Indonesia.

Mulliadi, D. 1996. Sifat Fenotipik Domba Priangan di Kabupaten Pandeglang dan Garut. Disertasi. Program Pascasarjana. IPB. Bogor.

Natasasmita, A. dan Mudikdjo. 1979. Beternak Sapi dan Kerbau. Fakultas Peternakan, Institut Pertanian Bogor, Bogor.

Pasaribu, E.S. 2015. Identifikasi Sifat Kualitatif dan Kuantitatif Babi Lokal Dewasa di Kecamatan Sumbul, Kabupaten Dairi, Sumatera Utara. Students e-Journal, 4(2).

Poespa 1996. Pendugaan Ukuran Linear Tubuh Berdasarkan Estimasi Gigi. Yogyakarta: Gadjah Mada University Press.

Santosa, U. 2008. Mengelola Peternakan Sapi Secara Profesional. Jakarta: Penebar Swadaya.

Soewandi, B.D.P., Thalib, C., 2015. Pengembangan Ternak Babi Lokal di Indonesia. Wartazoa, 25(1): 39-46.

Sudjana 2002. Metode Statistika. Bandung: Penerbit Tarsito.

Supranto, J. 2000. Statistik: Teori \& Aplikasi. 6 ed. Jakarta: Erlangga.

Wahyu. 1997. Ilmu Nutrisi Ternak Unggas. Yogyakarta: Gadjah Mada University Press.

Warwick, E.J., Astuti, M. \& Hardjosubroto, W. 1990. Pemuliaan ternak. Gadjah Mada University Press. 